\title{
Big business in a small state: Rationales of higher education internationalisation in Latvia
}

Maia Chankseliani, Anya Wells

\begin{abstract}
There is growing international interest in how market imperatives interact with the sociocultural and academic rationales of higher education internationalisation. This study provides new empirical material to examine the core rationales of international student recruitment in Latvia, where international students constitute $10 \%$ of the total tertiary enrolments. The nuanced analysis of narrative data from the interviews with university international officers is complemented by the analysis of policy documents and numeric data from the government and the UNESCO Institute of Statistics. By carefully interpreting the evidence, the study shows that international student recruitment has been stimulated by the demographic calculus and driven by the economic rationale. Universities have played an active role in increasing the numbers of mobile students and many institutions seem to benefit from working closely with student recruitment agencies. The scale of university-agency collaboration appears to vary by the type of institution; those with lower entry requirements have more extensive business relations with agencies than the relatively more reputable institutions. The study advances the understanding of internationalisation by arguing that a focus on market imperatives can undermine socio-cultural, academic and political benefits of inbound student mobility, which are viewed by universities as inferior to the immediate pecuniary interest.
\end{abstract}

Keywords Higher education internationalisation, international student recruitment, Latvia, inbound mobility, commercialisation, recruitment agencies, small state

\section{Introduction}

Internationalisation is a vibrant area of contemporary higher education research, with international student mobility being recognised as the most tangible form of higher education internationalisation (Chankseliani and Hessel, 2016b; Pedro and Franco, 2016; Varghese, 2013). While there exists some literature on student mobility to major Anglophone destinations, such as the UK, the USA and Australia, research focusing on former Soviet Union destinations is surprisingly scarce. This region used to be a major destination for international students in the 1960s to 1980s (Guruz, 2011), with roots of student mobility dating back to the early years of the Cold War, when the rival powers worked on attracting 
international students, particularly from the Global South (De Wit, 2002; O’Mara, 2012; Varghese, 2008; Woodhall, 1987). Both the USA and the Soviet Union supported international student mobility as a diplomatic tool for gaining new allies and strengthening the existing ties. For almost half of the 20th century, the Baltic states were part of the Soviet Union, a country that organised international student recruitment centrally and hosted the majority of international students in the imperial centre - the Russian SSR. Despite Latvia's peripheral position, it used to be a popular destination for international students in Soviet times. For example, Riga Aviation Institute used to host international students from 93 different countries (Auers and Gubins, 2017). Subsequently, with the dissolution of the Soviet Union, the main rationale for attracting foreign students - the promotion of communist values - has disappeared.

The three Baltic countries - Estonia, Latvia and Lithuania - are small states, as defined by their population size. ${ }^{1}$ Small states are thought to have a priori limited opportunities to create economies of scale and develop internationally competitive higher education systems (Bray, 2011; Urbanovič and Wilkins, 2013); they are sometimes considered to be more nationalistic and thus less welcoming to large numbers of foreigners (Urbanovič et al., 2016). Despite this limitation, as the Baltic states have developed economically and transformed socially in the last two decades, the volume of inbound student mobility has increased, with more international students seeking educational opportunities in Latvia, Lithuania and Estonia (UNESCO, 2015). The number of international degree-mobile students enrolled at Latvian universities increased by 12.5 times in the last two decades, from 648 in 1995-1996 to 8137 in 2016-2017. ${ }^{2}$ At present, Latvia records one of the highest inbound mobility rates among former Soviet countries, with 8137 international degree-mobile students constituting almost $10 \%$ of the total tertiary enrolments (Ministry of Education and Science, 2017). The inbound mobility rate of $10 \%$ places Latvia on a par with France, Lebanon, China and Denmark, and far ahead of its neighbours Russia, Estonia and Lithuania (UNESCO, 2015). However, in the next decade or so these statistics may deteriorate as it is predicted that outbound student mobility will likely decline globally because of the dampening effect of the improved domestic provision on outbound student flows (British Council, 2018).

In the context of intensified global competition between nation-states and higher education institutions (HEIs), and the growing influence of non-state actors, this study uses narrative and numeric data to explore the perspectives of Latvian HEIs in relation to international student mobility, which is recognised as the most tangible form of higher education internationalisation. The study addresses the following research question: How do HEIs explain the core rationales of Latvian higher education internationalisation? The paper starts by outlining the conceptual framework for the study, which is followed by an overview of the Latvian higher education context. Subsequently, we explain the methodological approach to address the research question. This leads to the findings section, which presents the interview data to explain the core rationales of higher education internationalisation in Latvia. The final section of the paper offers concluding reflections.

\section{Conceptual framework}

Different analytical frameworks may be adopted when looking at international student mobility as the core domain of higher education internationalisation: state-centred, studentcentred and/or institution-centred. The existing literature has primarily focused on the micro aspects of individual decision-making rather than on the wider socio-economic, institutional and cultural contexts that may be associated with such decisions (Findlay, 2011; Van Mol 
and Timmerman, 2013). This paper develops the institution-centred approach to examine the case of Latvia.

As a varied and expansive phenomenon, higher education internationalisation can be driven by four categories of rationales: political, economic, academic and socio-cultural (De Wit, 2002; De Wit et al., 2015; Knight, 2012; Knight and De Wit, 1995), which are linked to the purposes of education more broadly (more on this in Chankseliani and Silova, 2018). The four categories of rationales adopt different shapes and meanings when applied to the domain of international student mobility in different global contexts. HEIs and nation-states that 'have designs on them' (Kerr, 1994: 6) may view international students as sources of income, a potential labour force, contributors to the local economy as consumers, ambassadors for the recipient country, contributors to the recipient country's innovation capacity, and contributors to the improvement of educational and research experiences of local students and staff, which increasingly relates to global university rankings. Since the mid-1990s there has been a gradual shift from a political to an economic rationale for higher education internationalisation (De Wit et al., 2015; Kreber, 2009; Luijten-Lub et al., 2005).

The economic rationale has been paramount in many contexts where international students are viewed as sources of income (Adnett, 2010; British Future and Universities UK, 2014; Chankseliani, 2017; De Wit, 2002; De Wit et al., 2015; Guruz, 2011; Marginson, 2013; Robertson, 2011; Rumbley and Altbach, 2015). Research findings from the traditional host countries such as the UK, the USA and Australia show how the incoming international students contribute financially by paying the direct and indirect costs of studying and living in the host country (Cantwell, 2015; Kell and Vogl, 2008; Rodan, 2009). A recent survey of international students in Latvia has shown that the total contributions of international students to Latvian higher education and the wider economy amounted to $€ 73$ million in 2015-2016; using four OECD multipliers to calculate the added value of higher education to the Latvian economy results in the figure of $€ 148$ million, making up $0.61 \%$ of GDP (Auers and Gubins, 2017).

The commodification of education has been addressed by a variety of authors in the last few decades (Becker, 1964; Lyotard, 1984; Nussbaum, 2012). Glonacal (global + national + local) (Marginson, 2004) competition for students and resources constitutes a major concern for universities globally, which they are trying to address using various strategies. One such strategy is engaging with third-party providers for student recruitment. Many of the HEIs in countries with significant international student populations sign contracts with student recruitment agencies in order to have a steadily growing number of new entrants every year. These firms receive commissions ranging between $10 \%$ and $18 \%$ of the first year's tuition fees per recruited student (ICEF Monitor, 2014). Such collaborations have created an English-medium foundation programme market that had an estimated global value of US\$825m in 2015 (Cambridge English and Study Portals, 2015).

Besides being seen as consumers, internationally mobile students have also been viewed as backdoor migrants, innovators, ambassadors, activists (Robertson, 2011); the new strangers (Murphy-Lejeune, 2003); Eurostars (Favell, 2011); globally mobile children (Nette and Hayden, 2007); globetrotters (Mahroum, 2000); self-initiated global careerists or accidental navigators (Ho, 2011); investors in geographical and social mobility (Marginson, 2011); and contributors to the future transnational capitalist class (Sklair, 2012). These imageries assume the existence of complex global representations that bring together the underlying currents of economic and non-economic rationales of international student mobility. Depending on the 
specific individual, institutional and national contexts, some of these images may be more fitting than others.

Non-economic rationales of higher education internationalisation have been linked with the development of national cultural identity and intercultural understanding, the advancement of democratic citizenship and the promotion of social and political change (Chankseliani, 2018; Knight, 2012). Furthermore, higher education internationalisation is associated with the expansion of an international dimension to research and teaching, the widening of the academic horizon, the support in institution-building, and the improvement of institutional profile and status (De Wit, 2002; Haigh, 2014). Clustering of international students can increase the diversity on campus and can also enhance the quality of learning experiences as well as attract more international students through students' networks at home (Wells, 2012). International students may contribute to the improvement of educational and research experiences of local students and academics and/or serve as important actors to help universities move up the ladder of globally competitive institutions (Bolsmann and Miller, 2008; Horta, 2009). Building an international name brand or international 'symbolic capital' (Baker and Brown, 2007) can help institutions become more visible internationally (Rumbley and Altbach, 2015) in order to attract more diverse and intellectually curious students. Thus, internationalisation can help universities to serve the public interest locally and globally. In this respect, internationalisation can be a major transformative force in small-state contexts.

\section{Latvian context of higher education internationalisation}

Following the fall of communism, Latvian higher education expanded dramatically, and currently consists of 58 HEIs and colleges operating in a small state of up to two million residents (Ministry of Education and Science, 2017). Like other countries in the region, higher education expansion was accompanied by increasing hierarchical differentiation (Dobbins and Kwiek, 2017) and, to a certain extent, was an outcome of the development of a new sector - private higher education. Approximately $40 \%$ of universities in Latvia are nonstate (OECD, 2017) where the Latvian government funds a certain number of students per discipline. It has been argued that the emergence of non-state institutions could have been stimulated by making the public funding available to them (Chankseliani, 2014). The expansion of higher education has improved access for students from traditional and nontraditional backgrounds. Whereas in 2005 only $22 \%$ of 25-34 year-olds in Latvia had received tertiary education, in 2015 the proportion almost doubled and reached 40\% (OECD, 2017: 5).

Since 2007, fewer of the Latvia-domiciled students have been entering universities. Two contributing factors could have been the decreasing numbers of young people in the Latvian population and high levels of migration, including for the purpose of pursuing higher education abroad. The EU accession in 2004 made it easier and more affordable to move across borders (Chankseliani and Hessel, 2016a, 2016b). Latvian universities experienced another blow during the financial crisis in 2008-2009 when the Latvian higher education budget was reduced by 50\% (Mhamed et al., 2018; OECD, 2017). In these circumstances, HEIs in Latvia have been trying to attract more international students and at the same time persuade Latvian students to enrol at home. Latvian HEIs have been successful in recruiting international students. The number of international degree-mobile students enrolled at Latvian HEIs has increased by 12.5 times in the last two decades, from 648 in 1995-1996 to 8137 in 2016-2017. The countries sending the most numbers of students to Latvia are 
Germany, Uzbekistan, India, Russia, Sweden, Kazakhstan, France, Ukraine, Turkey and Lithuania (Ministry of Education and Science, 2017).

The most popular fields of study for international students are social sciences and business management, followed by medicine and health care. Subject choices are linked to the regions of origin: students from former Soviet countries favour social sciences and business management, while European students often enrol in medical sciences. Students from Asia tend to choose engineering, medicine, or social sciences (Auers and Gubins, 2017).

The principal language of instruction in the country is the state language, Latvian, but there are a number of university programmes offered in two foreign languages, English and Russian. State universities can only offer programmes in the official languages of the European Union (Latvian Parliament, 1999) which means that only non-state institutions can offer programmes in Russian (Mhamed et al., 2018). English is a much more popular language of instruction, with 262 degree programme offerings, than Russian, which has only 21 degree programme offerings (StudyinLatvia, 2017).

Latvian higher education is decentralised. Universities are autonomous in designing education programmes, determining organisational procedures, distributing allocated funding, establishing rules and regulations and hiring staff (OECD, 2017). Unlike the neighbouring Estonia and Lithuania, Latvia has not developed a national strategy of higher education internationalisation. In this context, the government acts as a stimulator of internationalisation and recognises it as a key policy priority (Council of Higher Education, 2013; Cross-Sectoral Coordination Centre, 2012; Ministry of Economics, 2013, 2014; Parliament of Latvia, 2010; World Bank, 2014). The National Development Plan 2014-2020 specifies measures that support higher education exports, such as the development of joint programmes in EU languages in no fewer than 10 fields of study; international publicity of the study programmes; the development of support centres for international students; and recruitment of instructors from other countries (Cross-Sectoral Coordination Centre, 2012: $31)$. In the last few years, Latvian universities have started offering joint programmes with universities from abroad. Some of the HEIs offer international students state-funded scholarships. The State Education Development Agency maintains the website www.studyinlatvia.lv, which provides information to international students on Latvian higher education, residence permits and life in Latvia. There also exists a national agency - the Academic Information Centre - that supports universities in preparation for international education fairs; many interviewees seem to have benefited from this support, especially when working with countries where they did not have extensive networks, such as Brazil, Malaysia, South Africa, Vietnam and China.

As part of the HEI-driven internationalisation effort, the non-profit Higher Education Export Association was founded in 2011 by Riga Technical University, the University of Latvia, and the School of Business Administration Turiba. The Higher Education Export Association aims to develop Latvian higher education export capacity and to promote internationalisation (Riga Graduate School of Law, 2014). As a respondent explained, the association has placed universities in a better position when negotiating with the Ministry of Education, as they can now speak collectively rather than individually.

\section{Methodological approach}


This study relied on interviews with university international officers as the main method of data collection. In-depth semi-structured individual interviews were used to explore the university international officers' understanding of higher education internationalisation in Latvia. The relative flexibility of the method as well as a maximum variation sampling approach allowed us to gain access to different bodies of knowledge and experiences.

Our sample included the international student recruitment officers from eight out of 58 Latvian HEIs. We interviewed one international student recruitment officer from each institution. All participants were knowledgeable about the strategic and administrative aspects of recruitment and admissions as well as the teaching practices at their institutions. While Latvian universities provide courses in a variety of subject areas, HEIs typically focus on a limited number of specialisations (Academic Information Centre, 2002). This study was not designed to draw comparisons between HEIs with or without a university status, and although Table 1 differentiates universities from other HEIs, in this paper the term 'universities' is used interchangeably with 'HEIs' (Table 1).

Table 1. The sample of Latvian HEIs by the degree of internationalisation, type, age, and legal status, $2016 / 17$

\begin{tabular}{llllll}
\hline $\begin{array}{l}\text { Numeric } \\
\text { identifier of } \\
\text { HEI }\end{array}$ & $\begin{array}{l}\text { Rate of } \\
\text { international } \\
\text { isation } \% \text { of } \\
\text { international } \\
\text { students) }\end{array}$ & $\begin{array}{l}\text { Number of } \\
\text { students inal } \\
\text { stude/17 }\end{array}$ & Type & Age & Legal status \\
\hline 1 & $32 \%$ & 437 & HEI & Post-1990s & Non-state \\
\hline 2 & $22 \%$ & 1837 & University & Pre-1990s & State \\
\hline 3 & $20 \%$ & 77 & HEI & Post-1990s & Non-state \\
\hline 4 & $15 \%$ & 569 & HEI & Post-1990s & Non-state \\
\hline 5 & $8 \%$ & 72 & HEI & Post-1990s & State \\
\hline 6 & $7 \%$ & 831 & University & Pre-1990s & State \\
\hline 7 & $6 \%$ & 65 & HEI & Post-1990s & Non-state \\
\hline 8 & $1 \%$ & 10 & HEI & Pre-1990s & State \\
\hline
\end{tabular}

The following characteristics were considered when selecting a maximum variation sample of Latvian HEIs: the rate of internationalisation, type, age and legal status of HEIs. These were selected as key dimensions of variation based on our knowledge of the Latvian higher education context, substantive literature and logic. Institutions in our sample vary by the rate of internationalisation, ranging from $32 \%$ of the student body being international to only $1 \%$ of the students coming from abroad (Table 1). Three out of eight are pre-1990s institutions and five were established in the 1990s. In terms of their legal status (state/non-state), there is an equal split of HEIs, broadly reflecting the Latvian higher education landscape whereby approximately $40 \%$ of HEIs are non-state (OECD, 2017). Seven out of eight institutions in the sample are located in Riga, the capital of Latvia and the largest city in the Baltic states, where $98 \%$ of international students congregate (Auers and Gubins, 2017). Thus, the maximum variation sampling allowed us to cover the spectrum of positions and perspectives in relation to internationalisation and included what can be considered both extreme and typical cases. In what follows, numbers in brackets represent numeric identifiers of the HEIs interviewed. 
Semi-structured interviewing was the main method for addressing our research questions; it allowed us to generate rich accounts of Latvian higher education internationalisation by establishing direct contact with the participants to explicate the meanings of their responses. Interviewing provided the flexibility to gather details and prompted illuminating discussions on selected aspects of the institutional rationales and the main actors of internationalisation. Our interview questions related to the patterns of inbound student mobility, the interviewees' understanding of Latvian higher education internationalisation, their views on international students, the practice of their recruitment and the roles of the main actors in the process of student mobility and internationalisation.

The interview participants were identified through the websites of HEIs and interviews were conducted from February to June 2016 in Russian, Latvian, or English. The data collected from the international student recruitment officers were fully transcribed and analysed in several stages. The first stage involved transcribing and close reading, which was followed by the breaking down of the narratives into themes of interest. We identified both a priori and newly-emerging themes using NVivo10 software across all transcripts. Finally, the themes were merged into a narrative expanding on and interpreting the core question of interest how respondents explained the rationales for higher education internationalisation in Latvia.

This study rests on two important assumptions. First, by relying on self-reporting, we assume that the university international officers serve as reliable sources of information on the rationales for higher education internationalisation in Latvia. Second, the study gathered data from a small group of university international officers. The exploratory nature of this research relied on the 'logic of discovery' instead of the 'logic of verification' (Luker, 2010). Empirical generalisation was not a goal of this study. Instead, by aiming at a theoretical generalisation of these findings, we used the rich data generated from the semi-structured interviews to explore how the university international officers explain the rationales for Latvian higher education internationalisation.

\section{Rationales for higher education internationalisation in Latvia}

All participants of this study recognised international student recruitment as the dominant form of higher education internationalisation in the Latvian context. There was a broad consensus that although the rationales for internationalisation may differ by the locality and the institution, the economic rationale was at the centre of Latvian universities' efforts to recruit more international students. This section starts by presenting the evidence on the economic rationale for higher education internationalisation in Latvia and moves to the analysis of non-economic rationales. It is shown that demographic trends and cuts in government funding incentivised Latvian HEIs to intensify international student recruitment. The main strategic choices of universities, such as extensive collaborations with student recruitment agencies as well as selection of countries for student recruitment, were largely driven by economic considerations. Furthermore, the findings demonstrate that, while university income-generating activities were viewed as central, the universities also thought about the broader economic benefits for Latvian communities but did not consider the benefits in terms of the labour market contributions of their graduates. This section then also analyses the academic, socio-cultural and political rationales for higher education internationalisation in Latvia and describes in detail some challenges brought by internationalisation related to the diversity of the student body. 
Higher education was viewed by the majority of respondents as a commodity to be traded globally, and two factors emerged as contributors to this view: the changing demographic situation in Latvia and cuts in government funding. The demographic trends included shrinkage of the relevant age group entering universities as well as progressively larger numbers of Latvian students choosing to study or work abroad. The cuts in government funding coincided with the demographic problems of decreasing numbers of university-age students, leading to 'drama following another drama, [where it has been] really tough to survive' (3). In this context, intensifying international student recruitment was one of the key mechanisms to 'survive with a certain level of students at the university' (6). The concept of 'survival' emerged in a number of interviews, with one of the study participants echoing other respondents' sentiments that they were 'struggling to survive' (7). The government was not viewed as particularly helpful when it came to HEIs' survival struggles. While some of the respondents confirmed that the government supported higher education internationalisation by providing funds for marketing, others were critical of the government policies and argued that the support was not sufficient. Narratives revealed that the government viewed internationalisation as the responsibility of HEIs: 'I do think that universities are quite on their own when it comes to recruiting, attracting international students', argued a respondent (2). Therefore, many participants of this study attributed the success achieved in the process of internationalisation to their own institutional, rather than government, efforts.

Most participants talked about ambitious targets of increasing the proportions of international enrolments at their institutions. Nationally, the government target of $8 \%$ of international enrolments (World Bank, 2014) had been achieved, but three out of eight participants were still aiming to achieve the $8 \%$ target (Table 1). Some others had their own much higher targets for international student recruitment. For example, one of the institutions participating in this study had $15 \%$ of their students coming from abroad and aimed to achieve a $30 \%$ inbound mobility rate by 2020 .

Driven by the economic rationale to secure a steady supply of international students, Latvian HEIs have developed extensive collaborations with student recruitment agencies. Such firms connect universities with potential applicants and their families, help with information exchange and networking and ensure that international applicants go through the entire selection procedure successfully and enrol at the university. In the process of connecting applicants with universities, and through the so-called 'pathway programmes', for-profit firms accumulate large benefits from 'selling' potential students to universities, and the latter benefit from the fees that these students pay. In the era of education commercialisation, international student recruitment is becoming 'big business' in Latvia, where agents advertise and market programmes of study, prepare education fairs and work with secondary schools abroad. There were cases where agents managed university communication with all of their international applicants: 'we actually never meet with a student until they come to Latvia. All my communication is with the agents' (5). All of the institutions participating in this study had links with at least one agency. One respondent described the links between universities and agencies in some detail:

They are recruiting the students on behalf of us because in every country students need a contact point. Agencies are the contact point. They are the universities' representatives. We all go to other countries one or two or maybe three times a year for fairs, seminars. Agents are in those countries and students can contact them directly. Of course, they organise for us seminars, presentations, and meetings with parents. And the students arrive and there are 
some questions from the parents' side or if we have to send some message to the parents we use this agent. Selecting the agents is very hard work. (4)

Most of the participants in this study viewed the recruitment via private firms as a beneficial 'business activity that is gaining momentum little by little. Everybody wants a bite of this pie' (7). However, in the context where the market was saturated with agents, finding an agent that would work with an educational institution exclusively and would be devoted to the single institution's interests was not so easy (6). The analysis of institutional characteristics by the extent of their engagement with agencies revealed that larger HEIs with lower entry requirements appeared to have more extensive and successful engagement with recruitment agencies than HEIs with higher entry requirements:

It's always attractive to earn much more of their fees from schools that have lower requirements and where they can get in many more students. Whenever they attract students, we usually say that they still need to comply with general requirements for admission, we don't care that they were attracted by agents, but we need them to comply with the requirements and I can honestly say that we haven't been that impressed by the quality that we get from the agents. (3)

Agents are paid fees by universities per recruited student and these fees come from student tuition payments. In order to attract a large number of international students, the Latvian higher education sector chose to keep tuition fees within a reasonable range, between $€ 2000$ and $€ 6000$, varying by specialisation and by institution. In most cases, there is not a large difference between fees for home/EU and non-EU students for undergraduate study programmes. For masters' programmes, the fees are usually higher for non-EU students than for home/EU students (StudyinLatvia, 2017). What was reported as reasonable fees allegedly stimulated the economy of scale: 'we are attractive due to our prices.... This is a marketing project where we hope that once we have a certain number of students, it will turn into some profit' (7). This 'marketing project', that showcases the country as an attractive destination for international students, also influenced the perceptions of the quality of Latvian higher education, as argued by interviewees. 'If you have international students, it means that you have a rather good quality of education' (6) and can move up the ladder of globally competitive institutions, thus generating even higher profits.

Although the cost of studying in Latvia is significantly lower than the cost of studying in some of the most popular global destinations, not everyone can afford it. Besides the tuition costs, international students have to incur the average annual costs for housing (ranging from $€ 2338$ to $€ 4332$ ) and living expenses (€3696) (Auers and Gubins, 2017). The ability to pay and the population size emerged as two key variables when university representatives spoke about source countries. The idea of 'the smaller the country, the less we can get' (8) seemed to influence how some of the respondents thought about sending countries. Many of the largest senders to Latvia, such as Germany, Uzbekistan, India, Russia, Kazakhstan, France, Ukraine and Turkey have large populations and/or a sizable middle class that can afford to finance studying abroad. Furthermore, most of these nations have well-developed higher education systems and provide ample, although perhaps not equitably distributed, opportunities to access universities at home. However, this list also includes nations with limited higher education capacity and growing population, such as Uzbekistan or India. This confirms that countries with low tertiary capacity and underdeveloped labour markets are more likely to have higher proportions of students studying abroad (Chankseliani, 2016). Apparently, Latvian HEIs found Uzbekistan a good source of students. One of the 
respondents explained that with a high demand for university education, families in Uzbekistan have to look for higher education opportunities abroad and Latvia seems to be a very attractive destination to them (7).

Some of the respondents expanded on the economic benefits of higher education internationalisation for wider communities: 'if we take the tuition fees and also everyday needs they are covering in Riga and Latvia, then if we have more international students, it means the profit is not only for the university but also for the regions and for Riga itself' (6). However, the views on benefits did not reach beyond the immediate cashflow; for example, respondents did not mention the potential benefits related to the possibility of international graduates joining the workforce and thus helping Latvia address the problem of its ageing population. Attempts by international applicants to enter Latvian HEIs in order to find employment afterwards were viewed as an attempt at backdoor migration, and India and Africa were seen as the biggest sources of potential labour migrants. While there was a lot of interest from Africa, some of the participants indicated that they did not even respond to queries from African countries, as the likelihood of those students receiving visas was minimal (7). Another respondent mentioned that they were approached by private firms who offered 'good deals' to facilitate admission for 'students' who would like to obtain a residence permit in Latvia but would not necessarily pursue their studies (3). In contrast, Kazakhstan, Uzbekistan, Russia and Georgia were seen as the least likely sources of potential labour migrants. One interviewee explained: '[Uzbek students] are not seeking a foothold to remain in the European Union' (7).

In some of the key sending countries, such as Uzbekistan, Turkey or India, the youth unemployment figures are high and graduates may aspire to gain temporary or long-term employment in Latvia, thus contributing to the broad economic and social issues stemming from the problem of an ageing population. In The National Concept for the Development of Higher Education and Institutions of Higher Education of Latvia for 2013-2020, the Council of Higher Education describes international student recruitment not only as 'the source of income but also as the potential human capital that would be worth attracting to Latvia thus compensating the drain of Latvian manpower' (Council of Higher Education, 2013: 14-15). The fact that this potential benefit was not acknowledged by any respondent of this study could possibly stem from an inclination of the Latvian public to view international students as a 'threat to [the] economy' (Wulz and Rainer, 2015: 55).

When discussing the non-economic rationales for higher education internationalisation, respondents mostly referred to the academic and socio-cultural rationales for recruiting international students; these two appeared to be closely intertwined in the Latvian context. Overall, the interview data revealed that the non-economic rationales for international student recruitment were not as strong as the economic rationale. The literature links the social and cultural rationales with national cultural identity, intercultural understanding, citizenship development and social and community development (Knight, 2012). The academic rationale, on the other hand, is usually related to providing an international dimension to research and teaching, extension of the academic horizon, institution-building, profile and status (De Wit, 2002), which translates into the global university ranking positions (Bolsmann and Miller, 2008; Boyadjieva, 2017; Horta, 2009). Some of these themes did emerge in the interviews.

A number of participants recognised that international students contributed to the improvement of learning experiences of all students because of the knowledge of other 
cultures that they brought to Latvia: 'they come here and they share their culture with us. Asia, Sri Lanka or India used to seem so far, but now we know more about these places' (5). International students introduced new perspectives to academic environments in terms of the diversity of approaches to a variety of issues discussed in classrooms: 'they bring a lot, I can say from our perspective we are also learning, when new students come and they share their opinions, and they share their visions' (3). One of the participants spoke about the importance of enrolling international students from extremely poor and underrepresented countries, such as Sudan or Rwanda. The respondent noted that these were not normally the most outstanding students academically, but they were valuable participants of academic discussions on various topics such as human rights and international development. These students, it was argued, made group discussions 'much more relevant, much more interesting and the whole atmosphere within [the institution] much more international and challenging' (3). International students were also perceived as 'the class of strong, open-minded people who are most actively participating in student life' (1). Some respondents even shared the impressions of their academic colleagues who saw diversity as a positive factor because 'you can't achieve much when you have a homogeneous classroom' (6). Thus, most of the participants of this study were very aware of the academic rationale for internationalisation in Latvia. However, in some cases diversity was viewed more as a challenge than an opportunity:

Internationalisation is a big challenge for the universities right now, and for society. Because we are a small nation, here it is visible when we have a student from India or a student from Asia and it will be a big challenge for society. I am really proud of those colleagues who work for internationalisation in all universities in Latvia because it is a job with a big challenge and a big drive. (4)

Applications from some localities - labelled as 'terrorist states' in the interviews - were not even given consideration for admission at some of the universities. One of the interviewees talked about 'negative' countries such as Pakistan, Nepal, Bangladesh and Egypt, and explained that even in those rare cases when students from these countries were admitted, having 'been studied under a magnifying glass', they were unable to obtain a residence permit (7). Thus, to avoid misleading the students, the interviewee said that they refused to consider applications from these countries altogether, even when they had sufficient evidence on the strengths of the applicant:

one Pakistani girl came to me, for example, I had to admit that she spoke English perfectly, she was very smart, a nice girl and I am sure a good student. Why are people like her not being let in? It is hard for me to say. I am sure that in Pakistan there are also nice people who would want to study and could study. (7)

Cultural differences appeared to be awkward to deal with, even in those cases when interviewees mentioned countries with no terrorism background, such as India. International students from selected areas of origin were perceived as starkly different from Latvians to the extent that 'sometimes this is almost shocking, for example, the differences in India and in Latvia' (8). Thus, at times cultural diversity was viewed as a negative rationale for internationalisation, to the extent that some of the interviewees contemplated plans to educate students in such locations via distance learning programmes that they were designing (7).

The language of instruction was an aspect of internationalisation that seemed to be directly linked with socio-cultural and academic rationales. Approaches to using English as a medium 
of instruction (EMI) were not homogeneous across the study participants. A few of the respondents viewed EMI as violating their universities' freedom to teach in the native language. Some others said EMI was passionately promoted at their institutions, as a measure that advances internationalisation in university teaching and research. Yet others accepted EMI as a necessary evil.

Despite being rather cautious about accepting students from selected backgrounds and sometimes sceptical about teaching in foreign languages, the interviewees always acknowledged the economic value of international mobility and also recognised the political/diplomatic value of hosting international students from locations that were culturally similar to Latvia, such as post-Soviet Eurasia, as well as the countries outside the former socialist context. In some narratives, there emerged a belief that it was important to offer tertiary education to the youth from former Soviet countries that were keen to learn about the successful Latvian example of transition. To some extent, providing an opportunity to study in the EU was perceived as technical assistance by Latvian people to the people from postSoviet Eurasia. The interviewees' sentiments on supplying educational aid, however, were not as strong as their rationales for educational trade.

Many of the interviewees confirmed that the Latvian HEIs had been working on developing good working relationships with students and educational institutions in ex-Soviet countries. The interest of students from former Soviet countries was explained by good links with the Latvian higher education sector, Russian and English as mediums of instruction, diaspora links, the appeal of living in the EU and the relatively low cost of tuition and living. Some participants also mentioned 'former good cooperation' with post-Soviet countries and the knowledge of Russian in these countries (6). However, most of the respondents rarely failed to go back to the economic aspect of hosting these students, indicating that despite the strong interest in studying in Latvia, many students in Central Asia were unable to afford the costs:

Last September my colleague and I were participating in an educational fair organised by the European Commission in Kazakhstan. Unfortunately, the interest during the fair was quite big. A lot of young people were standing by and would take our pens and brochures, but at the end of the day when it comes to receiving applications the interest was quite small. (2)

The interest in Latvia in countries outside the EU and the Eastern Partnership ${ }^{3}$ was negligible. In the last couple of years, the Ministry of Education has focused on supporting student recruitment from the Eastern Partnership countries in particular (4). This was explained by linguistic factors (e.g. students from Latin America and the Caribbean, it was argued, were more comfortable applying to Spanish/Portuguese language programmes), as well as by political links with different regions: 'For the university, these regions are the same as for Latvia itself. Our policy documents indicate that the EU countries and the Eastern Partnership are becoming increasingly important. And certainly, we have different bilateral agreements with countries of the Eastern Partnership' (6).

Many of the respondents also indicated that their institutions and the government wanted to reach out to the countries where Latvia was less well-known: 'The MFA sent the most interesting message that international students are the best social ambassadors in the world, and we have to focus on them and support them because they spread the name of Latvia abroad' (4). Being aware of the positive aspects of more diverse learning environments, some of the interviewees recognised the double benefit of helping Latvia become a globalised 
society and also promoting Latvia in other countries by alumni acting as Latvian ambassadors (5).

They promote our country much better than probably formal Latvian government institutions or diplomatic missions, because they have the direct experience and if they go back, let's say to Germany, and recommend this university, then it is not just good for the university, but it is also good for the country, because it suggests that we can offer a good education (2).

However, most of the narratives of students as ambassadors advertising Latvian education, were often linked back to the economic benefits this would bring to Latvia: 'You can use alumni to market your education within particular countries and also to ask them to be your agents' (6).

Finally, although international students were mostly viewed as a challenge, albeit a profitgenerating challenge, for the higher education system, some of the respondents also believed that in the long run they would strengthen the system and make it even better.

[student mobility] makes our educational system, our university stronger, because international students are more challenging in terms of their cultural background, of their previous personal background, and in terms of their expectations. Thus, I do think they strengthen our educational system and our universities (2).

\section{Concluding reflections}

In the context marked by growing glonacal competition in higher education and the expanding influence of non-state actors, this study explored how Latvian universities explain their rationales for internationalisation. The themes that emerged from this study appear to be aligned with the existing literature that recognises international student mobility as the principal manifestation of higher education internationalisation and economic interests as key drivers of internationalisation. The higher education sector in Latvia is highly commercialised. In the last two and a half decades, the higher education scene in this formerly communist country has transformed into a competitive market, where institutions describe students as consumers and see the main rationale for attracting international students in immediate pecuniary benefits. The demographic calculus and the financial crises have stimulated profit-seeking behaviour by Latvian universities and higher education has turned into a commodity that universities can trade globally to those who can afford it. The Latvian case seems to display some commonalities with the higher education marketisation trends in the neighbouring country Lithuania (Urbanovič et al., 2016), demonstrating that, despite being a small state with limited opportunities to create economies of scale and develop an internationally competitive higher education system (Bray, 2011; Urbanovič and Wilkins, 2013), its rather savvy universities have been successfully expanding the higher education sector and increasingly viewing internationalisation as big business.

This study has also shown that student recruitment agencies are undeniably important actors in the process of higher education internationalisation. Although university engagement with commercial firms is an underresearched topic, the international literature advises that when working with commercial firms, 'serious questions and conflicts may arise concerning the extent to which the third party provider's business model is compatible with the mission and objectives of a not-for-profit higher education institution' (Rumbley and Altbach, 2015: 8). 
Phillip Altbach develops an extreme view that the only solution to the problem of unethical conduct by third-party recruiters is the abolition or severe curtailing of such agencies (Altbach, 2010), while Wells (2012) warns that although international student recruitment agencies do not always work in students' or universities' best interests, they will continue to exist as long as there is demand for their services, and the best that the governments can do is to lay down professional guidelines for their operations and procedures of control, such as accreditation.

More importantly, this study has demonstrated that the growing reliance on international students as a major source of income is linked with significant declines in government funding, as well as the demographic calculus in Latvia. Although some of the respondents argued that clustering of international students can increase diversity on campus and improve the quality of learning experiences, a few of the interviewees were sceptical about the cultural and academic contributions of international students, especially when it came to students from backgrounds that were considered to be culturally dissimilar from Latvia. The finding that cultural diversity can be viewed as a negative rationale for internationalisation is perhaps not unexpected, considering that small states are more nationalistic and thus less welcoming to large numbers of foreigners (Urbanovič et al., 2016).

Higher education internationalisation dates back to the early years of the Cold War. In those days, the aims of the USSR and the USA were more political than economic. At that time inbound student mobility was regarded as a long-term strategy for developing links with friends and foes and promoting respective socio-political philosophies. The political rationale for higher education internationalisation is not as strong nowadays as it used to be, although the two veterans - the USA and the Russian Federation - continue to make large investments in attracting students from abroad (Chankseliani, 2018; Malinovskiy and Chankseliani, 2018). As shown by this study, Latvia is a small state where inbound student mobility is viewed as big business that brings in considerable amounts of cash from abroad. At the same time, some universities see cultural threats in the influx of foreign students. With this evidence at hand, we raise two questions for further contemplation: How can the philosophy of being driven by profit be effectively reconciled with the philosophy of being motivated by the academic, socio-cultural and political reasons for educating foreign students? How and in what ways can institutions that are oriented to the profit generated from hosting international students avoid jeopardising the valuable long-term benefits of student mobility, such as educating internationally knowledgeable students for inter-culturally competent citizenship, advancing research and innovation, developing cultural links between nations and potentially facilitating socio-political transformations?

\section{Acknowledgements}

The authors would like to thank the participants of this study for their time and insights. We would also like to thank Study in Latvia, which helped us with the required information and data.

\section{Notes}

1.Estonia has a population of 1.3 million, Latvia 1.9 million and Lithuania 2.8 million (World Bank, 2018). 
2.For the purposes of this study, internationally mobile students are defined as those who pursue a university degree (and not short-term, for-credit courses or exchange programmes for less than an academic year) abroad.

3.The Eastern Partnership involves the EU member states and six eastern European partners: Armenia, Azerbaijan, Belarus, Georgia, Moldova and Ukraine. The partnership is based on a commitment to the values of democracy, the rule of law, human rights and freedoms, market economy, sustainable development and good governance (European External Action Service, 2016).

\section{References}

Academic Information Centre (2002) Education system of Latvia (for diploma supplements). Available at: http://www.aic.Iv/rec/LV/leg_Iv/LVsysEN.htm (accessed 14 November 2018).

Adnett, N (2010) The growth of international students and economic development: Friends or foes? Journal of Education Policy 25(5): 625-637.

Altbach, P (2010) Bottom (line) feeders. Inside Higher Education. Available at: https://www.insidehighered.com/views/2010/08/23/bottom-line-feeders (accessed 24 April 2017)

Auers, D, Gubins, S (2017) Augstākās izglītības eksporta ekonomiskā nozīme un ietekme Latvijā [The economic value of higher education export for Latvia]. Available at:

http://certusdomnica.lv/agenda/augstakas-izglitibas-eksporta-ekonomiska-nozime-un-ietekmelatvija/ (accessed 4 April 2017).

Baker, S, Brown, B (2007) Images of excellence: Constructions of institutional prestige and reflections in the university choice process. British Journal of Sociology of Education 28(3): 377-391.

Becker, G (1964) Human Capital: A Theoretical and Empirical Analysis, with Special Reference to Education. New York: National Bureau of Economic Research.

Bolsmann, C, Miller, H (2008) International student recruitment to universities in England: Discourse, rationales and globalisation. Globalisation, Societies and Education 6(1): 75-88.

Boyadjieva, P (2017) Invisible higher education: Higher education institutions from Central and Eastern Europe in global rankings. European Educational Research Journal 16(5): 529-546.

Bray, M (2011) The small-states paradigm and its evolution. In: Martin, M, Bray, M (eds) Tertiary Education in Small States: Planning in the Context of Globalization. Paris: UNESCO Publishing, pp.37-72. Available at: http://unesdoc.unesco.org/images/0021/002121/212196E.pdf.

British Council (2018) El Feature - International student mobility to 2027: Local investment, global outcomes. Report, British Council, UK, January. Available at:

https://ei.britishcouncil.org/educationintelligence/ei-feature-international-student-mobility-2027local-investment-global-outcome (accessed 5 February 2018). 
British Future and Universities UK (2014) Universities UK - International students and the UK immigration debate. Available at:

http://www.universitiesuk.ac.uk/highereducation/Pages/InternationalStudentsUKimmigrationDeba te.aspx\#.VkoOy79wtnk (accessed 16 November 2015).

Cambridge English and Study Portals (2015) New routes to higher education: the global rise of foundation programmes. The world's first global mapping of an expanding market. Cambridge English and Study Portals. Available at: http://www.cambridgeenglish.org/images/pathways-report2015.pdf (accessed 5 February 2019).

Cantwell, B (2015) Are international students cash cows? Examining the relationship between new international undergraduate enrollments and institutional revenue at public colleges and universities in the US. Journal of International Students 5(4): 512-525.

Chankseliani, M (2014) Are we using Friedman's roadmap? A comparative analysis of stimuli of private school enrolments in post-Soviet countries. International Journal of Educational Development 38: 13-21.

Chankseliani, M (2016) Escaping homelands with limited employment and tertiary education opportunities: Outbound student mobility from post-Soviet countries. Population, Space and Place 22(3): 301-316.

Chankseliani, M (2017) Four rationales of HE internationalisation: Perspectives of UK universities on attracting students from former Soviet countries. Journal of Studies in International Education 22(1): 53-70.

Chankseliani, M (2018) The politics of student mobility: Links between outbound student flows and the democratic development of post-Soviet Eurasia. International Journal of Educational Development 62: 281-288.

Chankseliani, M, Hessel, G (2016a) Case studies of the most popular European destinations for mobile students from Russia, Eastern Europe, Caucasus, and Central Asia. Research report. Oxford, UK: The Centre for Comparative and International Education, University of Oxford. Available at: https://ora.ox.ac.uk/objects/uuid:307e125e-6def-4b5e-8c3e-a984a6ddd2d1 (accessed 5 February 2019).

Chankseliani, M, Hessel, G (2016b) International student mobility from Russia, Eastern Europe, Caucasus, and Central Asia to the UK: trends, institutional rationales and strategies for student recruitment. Research report. Oxford, UK: The Centre for Comparative and International Education, University of Oxford. Available at: https://ora.ox.ac.uk/objects/uuid\%3Afdbb4023-16fe-4542-9b2b1b47993acf68 (accessed 5 February 2019). 
Chankseliani, M, Silova, I (2018) Reconfiguring Education Purposes, Policies, and Practices during Post-Socialist Transformations: Setting the stage. In: Chankseliani, M, Silova, I (eds) Comparing PostSocialist Transformations: Purposes, Policies, and Practices in Education. Oxford Studies in Comparative Education. Oxford: Symposium Books, pp.7-25.

Council of Higher Education (2013) Summary of The National Concept for the Development of Higher Education and Institutions of Higher Education of Latvia for 2013-2020. Available at: http://www.aip.lv/eng_dev_plan_curr.htm (accessed 14 December 2015).

Cross-Sectoral Coordination Centre (2012) National Development Plan 2014-2020. Cross-Sectoral Coordination Centre. Available at:

http://www.pkc.gov.lv/images/NAP2020\%20dokumenti/NDP2020_English_Final.pdf (accessed 5 February 2019).

de Wit, H (2002) Internationalization of Higher Education in the United States of America and Europe: A Historical, Comparative, and Conceptual Analysis. Westport: Greenwood Press.

de Wit, H, Hunter, F, Howard, L. (2015) Internationalisation of higher education. Brussels: European Parliament. Available at:

http://www.europarl.europa.eu/RegData/etudes/STUD/2015/540370/IPOL_STU\%282015\%295403 70_EN.pdf (accessed 5 February 2019).

Dobbins, M, Kwiek, M (2017) Europeanisation and globalisation in higher education in Central and Eastern Europe: 25 years of changes revisited (1990-2015). European Educational Research Journal 16(5): 519-528.

European External Action Service (2016) Eastern Partnership - European External Action Service European Commission. Available at: https://eeas.europa.eu/headquarters/headquartershomepage_en/419/Eastern Partnership (accessed 8 April 2017).

Favell, A (2011) Eurostars and Eurocities: Free Movement and Mobility in an Integrating Europe. John Wiley \& Sons.

Findlay, A (2011) An Assessment of supply and demand-side theorizations of international student mobility. International Migration 49(2): 162-190.

Guruz, K (2011) Higher Education and International Student Mobility in the Global Knowledge Economy. Albany: State University of New York Press. Available at: http://site.ebrary.com/lib/alltitles/docDetail.action?doclD=10574146 (accessed 2 May 2014).

Haigh, M (2014) From internationalisation to education for global citizenship: A multi-layered history. Higher Education Quarterly 68(1): 6-27.

Ho, EL-E (2011) Migration trajectories of 'highly skilled' middling transnationals: Singaporean transmigrants in London. Population, Space and Place 17(1): 116-129. 
Horta, H (2009) Global and national prominent universities: Internationalization, competitiveness and the role of the State. Higher Education 58(3): 387-405.

ICEF Monitor (2014) The Agent Question: New Data has the Answer. ICEF Monitor. Available at: http://monitor.icef.com/2014/09/the-agent-question-new-data-has-the-answer/ (accessed 5 February 2019).

Kell, P, Vogl, G (2008) Trans-national education: The politics of mobility, migration and the wellbeing of international students. International Journal of Asia: Pacific Studies 4(1): 21-31.

Kerr, C (1994) Higher Education Cannot Escape History: Issues for the Twenty-First Century. First Printing edition. Albany: State University of New York Press.

Knight, J (2012) Concepts, rationales, and interpretive frameworks in the internationalization of higher education. In: Deardorff, DK, de Wit, HD, Heyl, JDD. (eds) The SAGE Handbook of International Higher Education. Thousand Oaks: SAGE, pp.27-42.

Knight, J, de Wit, H (1995) Strategies for internationalisation of higher education: historical and conceptual perspectives. In: Hans, DW (ed) Strategies for Internationalisation of Higher Education: A Comparative Study of Australia, Canada, Europe and the United States of America. Amsterdam: European Association for International Education, pp.5-32.

Kreber, C (2009) Different perspectives on internationalization in higher education. New Directions for Teaching and Learning 2009(118): 1-14.

Latvian Parliamen t (1999) Education Law. The Parliament of the Republic of Latvia. Available at: http://www.unesco.org/education/edurights/media/docs/ec272c12dcbfb616544538178284d5149 66ea0ef.pdf (accessed 5 February 2019).

Luijten-Lub, A, Wende, MV der, Huisman, J (2005) On cooperation and competition: A comparative analysis of national policies for internationalisation of higher education in seven western European countries. Journal of Studies in International Education 9(2): 147-163.

Luker, K (2010) Salsa Dancing into the Social Sciences: Research in an Age of Info-Glut. Cambridge, MA; London: Harvard University Press.

Lyotard, J (1984) The Postmodern Condition: A Report on Knowledge. Manchester: Manchester University Press.

Mahroum, S (2000) Highly skilled globetrotters: Mapping the international migration of human capital. R\&D Management 30(1): 23-32.

Malinovskiy, S, Chankseliani, M (2018) International Student Recruitment in Russia: Heavy-handed Approach and Soft-Power Comeback. In: Oleksiyenko, A, Zha, Q, Chirikov, I. (eds) International Status Anxiety and Higher Education: The Soviet Legacy in China and Russia. Hong Kong: CERCSpringer, pp. 281-307. 
Marginson, S (2004) Competition and markets in higher education: A 'glonacal' analysis. Policy Futures in Education 2(2): 175-244.

Marginson, S (2011) Including the other: Regulation of the human rights of mobile students in a nation-bound world. Higher Education 63(4): 497-512.

Marginson, S (2013) The impossibility of capitalist markets in higher education. Journal of Education Policy 28(3): 1-18.

Mhamed, AAS, Vārpina, Z, Dedze, I. (2018) Latvia: A Historical Analysis of Transformation and Diversification of the Higher Education System. In: Huisman, J, Smolentseva, A, Froumin, I (eds) 25 Years of Transformations of Higher Education Systems in Post-Soviet Countries - Reform and Continuity. Palgrave Studies in Global Higher Education. Basingstoke: Palgrave Macmillan, pp. 259284.

Ministry of Economics (2013) Progress report on the implementation of the National Reform Programme of Latvia within the Europe 2020 strategy. Riga, Latvia: Ministry of Economics of the Republic of Latvia. Available at: https://ec.europa.eu/info/sites/info/files/file_import/nrp2013_latvia_en_0.pdf (accessed 5 February 2019).

Ministry of Education and Science (2017) Statistika par augstāko izglīīibu [Latvian Higher Education Key Statistics] 2016. Riga, Latvia: Ministry of Education and Science of the Republic of Latvia. Available at: http://izm.gov.Iv/Iv/publikacijas-un-statistika/statistika-par-izglitibu/statistika-paraugstako-izglitibu (accessed 10 July 2018).

Murphy-Lejeune, E (2003) Student Mobility and Narrative in Europe: The New Strangers. London: Routledge.

Nette, J, Hayden, M (2007) Globally mobile children: The sense of belonging. Educational Studies 33(4): 435-444.

Nussbaum, MC (2012) Not for Profit: Why Democracy Needs the Humanities. Princeton: Princeton University Press.

OECD (2017) Education Policy Outlook. Latvia. Paris: OECD Publishing. Available at: http://www.oecd.org/education/Education-Policy-Outlook-Country-Profile-Latvia.pdf (accessed 5 February 2019).

O'Mara, M (2012) The uses of the foreign student. Social Science History 36(4): 583-615.

Parliament of Latvia (2010) Sustainable development strategy of Latvia until 2030. Saeima of the Republic of Latvia. Available at: http://www.varam.gov.Iv/in_site/tools/download.php?file=files/text/dokumenti/pol_doc//LIAS_20 30_parluks_en.pdf (accessed 5 February 2019). 
Pedro, E, Franco, M (2016) The importance of networks in the transnational mobility of higher education students: Attraction and satisfaction of foreign mobility students at a public university. Studies in Higher Education 41(9): 1627-1655.

Riga Graduate School of Law (2014) Riga Graduate School of Law becomes a member of the Higher Education Export Association. Available at: http://www.rgsl.edu.Iv/en/news/riga-graduate-schoolof-law-becomes-a-member-of-the-higher-education-export-association (accessed 30 March 2017).

Robertson, S (2011) Cash cows, backdoor migrants, or activist citizens? International students, citizenship, and rights in Australia. Ethnic and Racial Studies 34(12): 2192-2211.

Rodan, $\mathrm{P}$ (2009) The international student as student, migrant and victim: Changing perceptions in a vexed area of public policy. Australian Universities' Review 51(2): 27-31.

Rumbley, L, Altbach, P (2015) The local and the global in higher education internationalization: A crucial nexus. In: Jones, E, Coelen, R, Beelen, J. (eds) Global and Local Internationalization. Rotterdam/Boston/Taipei: Sense Publishers. Available at: https://www.sensepublishers.com/catalogs/bookseries/global-perspectives-on-highereducation/global-and-local-internationalization/ (accessed 21 December 2015).

Sklair, L (2012) Transnational capitalist class. In: The Wiley-Blackwell Encyclopedia of Globalization. John Wiley \& Sons, Ltd.

StudyinLatvia (2017) Why study in Latvia? Available at: http://www.studyinlatvia.eu/en/how-toapply/tuition-fees (accessed 3 April 2017).

UNESCO (2015) UIS statistics on international student mobility in tertiary education. 2015 data. Available at: http://www.uis.unesco.org/Education/Pages/international-student-flow-viz.aspx (accessed 15 January 2018).

Urbanovič, J, Wilkins, S (2013) Internationalisation as a strategy to improve the quality of higher education in small states: Stakeholder perspectives in Lithuania. Higher Education Policy 26(3): 373396.

Urbanovič, J, Wilkins, S, Huisman, J (2016) Issues and challenges for small countries in attracting and hosting international students: The case of Lithuania. Studies in Higher Education 41(3): 491-507.

Van Mol, C, Timmerman, C (2013) Should I Stay or Should I Go? An Analysis of the Determinants of Intra-European Student Mobility. Population, Space and Place 20: 465-479. DOI: 10.1002/psp.1833

Varghese, N (2008) Globalization of Higher Education and Cross-border Student Mobility. Paris: ENESCO International Institute for Educational Planning.

Varghese, N (2013) Globalization and higher education: Changing trends in cross border education. Analytical Reports in International Education 5(1): 7-20. 
Wells, A (2012) Student mobility and competence development in higher education: A study of Latvian students at English universities. DPhil Thesis, University of Oxford, UK.

Woodhall, M (1987) Government policy towards overseas students: An international perspective. Higher Education Quarterly 41(2): 119-125.

World Bank (2014) Assessment of Current Funding Model's 'Strategic Fit' with Higher Education Policy Objectives. World Bank Reimbursable Advisory Service on Higher Education Financing in Latvia. World Bank Reimbursable Advisory Service on Higher Education Financing in Latvia. Available at: http://viaa.gov.lv/files/news/24067/lv_r2_strategic_fit_18april_vfinal.pdf (accessed 5 February 2019).

World Bank (2018) Data: Population, total. Available at:

https://data.worldbank.org/indicator/SP.POP.TOTL (accessed 19 November 2018).

Wulz, J, Rainer, F (2015) Challenges of student mobility in a cosmopolitan Europe. In: Curaj, A, Matei, L, Pricopie, R. (eds) The European Higher Education Area. Cham: Springer International Publishing, pp.43-59. Available at: http://link.springer.com/10.1007/978-3-319-20877-0 (accessed 17 October 2015). 